Patrycja RUTKOWSKA (1)

Nicolaus Copernicus University, Faculty of Political Sciences and International Studies, Toruń, Poland

Marcin A DA MCZYK

University of Wrocław, Faculty of Social Science, Poland

\title{
Arms Trade in the Current Military Relations between the People's Republic of China and Ukraine, and Its Role in Development of the Chinese Military Potential
}

Handel bronią w ramach współczesnych stosunków wojskowych Chińskiej Republiki Ludowej z Ukrainą oraz jego rola w rozwoju potencjału militarnego Chin

\section{- Abstrakt •}

Celem artykułu jest zbadanie i przedstawienie roli transferu technologii wojskowego sprzętu i uzbrojenia we wzajemnych stosunkach wojskowych ChRL i Ukrainy, a także jego wpływu na modernizację Chińskiej Armii Ludowo-Wyzwoleńczej i zwiększenie potencjału militarnego Chin.

Słowa kluczowe: Ukraina; Chiny; handel bronią; stosunki wojskowe; potencjał militarny
- Abstract •

The purpose of the article is to present and analyse the role of transfer of military technology, equipment and armaments in mutual military relations between the PRC and Ukraine, as well as its impact on modernization of the PLA and expansion of China's military potential.

Keywords: Ukraine; China; arms trade; military relations; military potential

\section{Introduction to the Research Problem}

The People's Republic of China (PRC) has - along with growing its economic potential, and increasing its significance in the Asia-Pacific region as well as globally - has been taking steps to enlarge its military potential. Its military ex- 
penditure (whose rate of growth inspires similar awe as China's economic growth) has been an undoubtedly crucial element in the process of modernization of the Chinese military forces (see Adamczyk, 2015, pp. 123-140). The need to close the technological gap between the Chinese People's Liberation Army (PLA) and the military forces of the broadly defined West, or even Russia, emerged from the ruins of the Soviet Union, is another crucial element in the process. Initially, China aimed to buy equipment and arms as well as to import technology directly from the West (see: Szulc, 2010, pp. 70-79). However, as a consequence of the Tiananmen Square Massacre, the European countries imposed an embargo on the PRC, which is in force to this day (SIPRI, 2018b; for a broader description see: Kamiński, 2015, pp. 134-142; Kreutz, 2004, pp. 43-58). The Russian Federation became another potential source of arms (see Donaldson, Donaldson, 2003, pp. 709-732; Adamczyk, 2016, pp. 173-192; Rangsimaporn, 2006, pp. 477-495), as Russia primarily saw a chance of saving at least a part of its excessively developed, post-Soviet arms industry in selling military technology to China. China was buying arms willingly enough, however not in large quantities and often with the permission (license) for further manufacturing in the country. As it turned out, it soon led to a tension between both countries - Moscow was not content with the fact that the arms sold were reproduced at a rapid pace at the Chinese factories. The rift only deepened when with time China started to successfully compete in arms trade against the original Russian designs in third-country markets. Consequently, although Russia is still the largest exporter of military equipment and arms to China (SIPRI, 2018c), the Middle Kingdom actively seeks alternative ways of obtaining post-Soviet military technologies, mainly from the most advanced countries of the former Soviet Union. In this situation Ukraine became a natural choice, as its defense industry survived the fall of the Soviet Union in a relatively good condition.

The aim of the present work is to examine what is the role of transfer of army technologies and arms in the overall military relationship between PRC and Ukraine, what is its impact on modernization of the PLA, and more broadly, growth of the Chinese military potential. We shall note that international military relations "(...) encompass primarily any form of military cooperation between the countries. Their main goal is to reassure the security of the parties of these relations (...)" (Molo, 2008, p. 25). At the same time, Maciej Karczewski highlights that "international arms trade brings together (...) political interests. The countries treat export of military technology as an important tool of their foreign policy. It is a way to initiate and sustain an effective way of influencing the power relations in key world regions" (2012, p. 59). On the other hand, Roman Kuźniar shows 
that supply of equipment and arms as well as military consultancy services constitute a crucial element in the range of military tools available in foreign policy towards associate countries (2006, p. 128). It is important to point out that the military relations between China and Ukraine are principally based on two main foundations: transfer of military technologies, arms and equipment. Due to the scale of the phenomenon and its importance for mutual military relations of these countries the authors decided to focus on arms trade ${ }^{1}$.

At this juncture, it is important to make several reservations to manage expectations as to the content of the present work. Despite many initiatives that aim at making the problem public and clear (see Macenowicz, 2015, pp. 263-280; Wezeman, Wezeman, 2015), the access to credible information regarding arms trade is hindered in the majority of the world's countries. In countries with a totalitarian and authoritarian background, such as the PRC, or countries that are not fully democratic, for example Ukraine, such information is inaccessible, scarce or provided by the government, according to their current political need $s^{2}$. The authors, aiming at a deep analysis of the problem, were forced to use mainly electronic data sources in the form of quantitative reports of the Stockholm International Peace Research Institute (SIPRI) and information provided by the interested countries to the United Nations Register of Conventional Arms (UNROCA), as well as analyses and news available made on official state web pages, and websites of foreign think tanks or specialized media. The authors take the position that electronic sources, which are still unpopular amongst researchers, when studied in sufficient detail constitute a valuable source of current information. At the same time, the topic itself and a limited number of scientific studies and sources available impose their wide use upon the authors. Of course, certain reservations concerning accuracy or credibility of some of the research material used here should be made - some information is unverified and carries the risk of, in the future, being revealed as purposeful misinformation. In order to minimize the risk inherent in using such sources and drawing erroneous conclusions based on them, the authors tried to use several concurrent sources each time to verify and confirm a given fact - hence the greater (comparable to that of a scientific paper) number of positions in the bibliography. The main research questions concern the role played by transfer of military technologies and equipment and arms in rela-

${ }^{1}$ Which, in international relations affairs, is understood as "actions encompassing export and import of arms, weaponry, spare parts, and military technology" (International Relations, 2018).

${ }^{2}$ Arms trade between China and Russia is fairly well described in global scientific literature. One must remember, however, that most of the works available concern the turn of the century, and not recent years. 
tions between the PRC and Ukraine; and the impact of this transfer on China specifically modernization of its armed forces and increase of its military potential.

\section{Peregrination of Equipment and Arms to China}

Ukraine managed, after the Cold War and the dissolution of the USSR, to preserve a relatively modern and well-developed arms industry (see: GlobalSecurity. org, 2017). Engineers from this country achieved considerable successes in developing and modernising post-soviet arms and equipment, which are extremely popular on global markets (see Zaloga 2011, p. 35; Gawęda, 2015) - according to SIPRI, between 2010 and 2016 Ukraine has ranked $9^{\text {th }}$ among arms exporting countries (2017b). In the aforementioned period, China was undeniably the biggest recipient of military technologies, equipment and arms from Ukraine (SIPRI, 2017a). Kiev was contracted to deliver to China hundreds of plane, tank, and ship engines, over a thousand air-to-air missiles, a handful of tanks, self-propelled guns, radars and planes, as well as four Bison-class air-cushioned landing craft (NATO reporting name Pomornik) and an unfinished hulk of the first ever aircraft carrier in the PLA Navy's history - Liaoning (the ex-soviet Varyag; SIPRI, 2018a; UNROCA, 2018). Both deliveries of the vessels to China should be discussed in a greater detail. Moreover, talented arms designers from Ukraine have been actively participating in modernisation of armaments belonging to the PLA and launching arms production in China itself (see Zhao, 2017; Wang, 2013).

\section{Air-Cushioned Landing Craft for China}

Under the 2009 agreement (worth nearly \$320 million) Ukraine committed itself to deliver two air-cushioned landing craft to the PRC and transfer the licence (likely with accompanying support of its engineers) for production of additional two on-site in China (SIPRI, 2018a). The first of the hovercrafts manufactured in Crimea was handed to the PLA in 2013, and the next one - in the following year (Dura, 2013; Altair, 2014) ${ }^{3}$. While in 2016 the first of the two hovercrafts manufactured under license was finished (Muczyński, 2016), in 2017 some sourc-

3 Interestingly, the second one was transferred faster because of the fear of losing the vessel due to uncertain situation on the peninsula. Ultimately, the hovercraft embarked on its long journey to China just before Crimea was entirely taken over by Russian forces (1 March 2014; Altair, 2014). 
es reported that a fifth carrier was being manufactured in the Chinese Huangpu Shipyard (Malyasov, 2017). Assuming that this information is true, it is still unclear whether Ukraine decided to expand the licence agreement to include construction of another ship, or if - as Maksymilian Dura suggested - since China's demand for a fleet of modern landing craft was so great, the country simply copied the delivered hovercraft, supplemented it with its own proprietary solutions and continued production without a licence (Dura, 2013).

Taking into consideration the fact that China has on numerous occasions copied Russian (and not only) technologies (see: Wezeman, 2017; Roblin, 2016; US Naval Institute Staff, 2015), the above does not seem improbable. To have a full picture of the issue, it is worth considering why Russia did not want to sell the hovercraft to China beforehand (Iwański, 2012, p. 5; RT, 2011). According to the authors, there are three reasons why Moscow is afraid/reluctant to sell modern equipment and arms, or even unique technologies, to China:

a) Risk that they would probably be copied and then illegally manufactured locally by Chinese plants (including their manufacturing for export, which would constitute a competition for the Russian defence industry) ${ }^{4}$;

b) a direct and serious threat for the security of Russia, if the arms/equipment were used in a conflict with Russia by China or any other third country which became a recipient of Chinese copies of the Russian equipment and arms

c) potential negative implications of a broad use of Russian-made equipment in a major conflict, which would bear the brunt of the blame for this threat to global peace and security.

It is undeniable that, considering the Chinese demand for fast and modern landing craft, the risk of unlawful copying of the delivered hovercraft, as mentioned by Dura, is not only dire but it has already happened. At the same time it should be remembered that these risks did not prevent Russia from eventually signing an agreement with China on the delivery of one of the most modern planes in the Russian arsenal - the SU-35 (Adamczyk, 2016, p. 185; Clover, Jiu, 2016). Moreover, it should be borne in mind that although the Bison/Zubr-class

${ }^{4}$ This not-so-potential-anymore threat to the Russian interests became apparent when a ChinesePakistani light fighter plane JF-17 (equipped with imported Russian engines) became a competition for MiG-29 aircraft in such countries as Azerbaijan, Myanmar, and Egypt (Page, 2010).

${ }^{5}$ A Russian military contingent in Syria had to fight against Islamist militants equipped with, among others, relatively new MANPADS (Man-portable air-defence system) portable rocket launchers and ATGMs (anti-tank guided missile; see: Adamczyk, 2016, p. 190; GlobalSecurity.org, 2018; Wolski, 2016a, p. 49; Wolski, 2016b, p. 47, 49). 
hovercraft, thanks to their considerable size and speed, are unique on a global scale (in the light landing hovercraft class), they were designed during the Cold War period. It is thus difficult to say that truly modern technologies were sold by Russia to China - especially as Moscow was surely aware that the blueprints (and two unfinished hulks) of hovercraft were in Ukraine's hands ${ }^{6}$, and the rest of air-cushioned landing craft were part of the Greek military ${ }^{7}$. Therefore, this particular argument seems not to really apply to the hovercraft example. Similar exception can be seen in the applicability of the argument of possible direct threat to the security of the Russian Federation - even leaving aside the current state of relations between the two countries, it is difficult to imagine a situation in which the Chinese Bison/Zubr-class hovercraft could constitute such a threat ${ }^{8}$. The only remaining explanation is that Russia feared it would be stigmatised for delivering fast landing hovercraft to the PRC which it could use in, for example, an invasion of Taiwan or to expand its control over the disputed islands to the East (for more see: Smith, 2013, pp. 27-44; Kaczmarek, 2012, pp. 61-73) and in the South China Sea (for more see: Brands, Cooper, 2018, pp. 13-32; Holmes 2014, pp. 30-51). It is clearly difficult to theorize about probability of any such conflict; although the option that Russia would be partly blamed, leading to imposing of sanctions similar to the ones put into force after the war in Ukraine cannot be excluded. Consequently, the prestige and credibility of the Russian Federation as a supplier of equipment and arms could suffer; moreover, countries against which the equipment (in this case fast landing hovercraft) would be used (e.g. India, the Philippines, Vietnam) could turn their backs on Russia. In the end, the Bison/

${ }^{6}$ Interestingly, as soon as the agreement between Kiev and China was signed, the rights to production of the hovercraft became a source of conflict between Ukraine and Russia (RT, 2011; Dura, 2013).

${ }^{7} \mathrm{NB}$, information about the sale of the Greek Zubr-class hovercraft to China was publicized at the end of 2014 (Kalman, Watson, Deiss, 2016; Dura, 2014b). However, there is no new information on the topic, nor any film/photo materials which would capture the fact that the craft were entered into the PLA Navy forces - which is surprising, considering how much information is available regarding the fate of the Ukrainian Bison-class hovercraft. The website of the Greek navy does not include any information about the hovercraft in its bookmark devoted to the current composition of the state's navy (Kalman, Watson, Deiss, 2016; Dura, 2014b); however, such a piece of information appears in the article devoted to Amphibious Operations Command (Hellenic Navy, 2018a). The authors, in order to dismiss any doubts, sent a relevant query to the Public Affairs Directorate itself. However, no reply has been received, and thus it is impossible to state what happened to the Greek hovercraft - neither SIPRI nor UNROCA have any information about the transaction in question (SIPRI, 2018; UNROCA, 2018).

${ }^{8}$ Purely hypothetically, in the opinion of the authors in any possible military conflict between China and Russia, the navy (and even moreso the fast landing hovercraft) would not play a major role - unlike the land and air forces. 
$Z u b r$-class fast landing air-cushioned craft were delivered to China (together with complete manufacturing documentation) by Ukraine (and probably by Greece too), thus realising the scenario outlined by Justyna Szczudlik-Tatar, in which Ukraine becomes one of the suppliers of Russian military technology to China instead of its original manufacturer (2011, pp. 2553-2554).

\section{Role of Ukraine in The Chinese Program of Aircraft Carriers}

The purchase of the aircraft carrier Varyag was undoubtedly the most spectacular transaction in the history of the Chinese-Ukrainian military relations. The second of the Soviet Kuznetsov-class vessels was 70\% complete and was waiting in a Black Sea shipyard when the Soviet Union dissolved. Initially, Russia was going to pay for completing the construction of the ship; however, it quickly withdrew this offer. Simultaneously, China attempted to purchase the unfinished aircraft carrier, also to opt out a while later (Storey, You, 2004, p. 82; Chan, 2015b; 2015d). As a consequence of the economic downfall of Russia, the state was forced to sell two aircraft cruisers - Minsk and Novosibirsk - to South Korea for breaking. The former, a Kiev-class carrier, was purchased by a Chinese company Minsk Aircraft Carrier Industry Company three years later (in 1998) and then anchored in Shenzhen, where it was transformed into a theme park. Interestingly, Boris Yeltsin is reported to have refused to sell Kiev and Minsk to China during his 1992 visit to

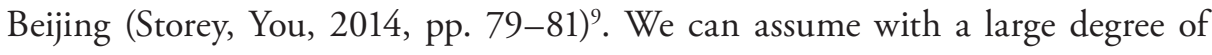
likelihood that the construction of the ship was analysed in detail by Chinese engineers. It should be noted that the peculiar construction of Soviet aircraft cruisers was, in many aspects, an obsolete one by then and from the start considered worse than construction of its western counterparts ${ }^{10}$. Russians were aware of that (what gave birth to the idea of building the three classic Kuznetsov-class aircraft carriers) and the Chinese seem to have been equally aware as in 1985 China purchased an out-of-service aircraft carrier HMAS Melbourne from Australia (Storey, You, 2004, p. 79; Szulc, 2013, p. 74; Behrendt, 2015, p. 37).

9 Perhaps Moscow at the time did not consider the scenario in which in a few years Russia would be forced, due to economic reasons, to scrap a major part of its fleet or, which is also probable, China was not perceived as a trustworthy ally.

${ }^{10}$ Rocket cruisers retained typical heavy offensive equipment at the cost of ability to carry out air operations - air groups of Kiev-class ships were composed of several Yak-38 light planes and $\mathrm{Ka}-25 / \mathrm{Ka}-27$ helicopters (they also lacked early warning machines). In effect, soviet aircraft carriers could not hold their ground against the western counterparts during the Cold War (in particular against American nuclear-powered aircraft carriers; see: Miller, Miller, 1994, passim). 
In the same year, China purchased the Minsk aircraft cruiser from South Korea, and attempted once more (this time successfully) to purchase the Varyag aircraft carrier. China used the same trick as beforehand, and an entertainment company from Hong Kong was the official purchaser. Its owner, $\mathrm{Xu}$ Zenping, announced that he would transform the carrier into a luxurious casino which was supposed to be located in the ex-Portuguese colony of Macau (Storey, You, 2004, p. 83; Szulc, 2013, p. 74; Chan, 2015a; 2015b; 2015d). In mid-1999, the transaction was completed and the ship embarked on a three-year journey to China - allegedly it did not have a working engine and had to be hauled to China ${ }^{11}$. Officially this is why Turkey kept refusing to grant a permit for the vessel's transit through the Bosporus strait for nearly a year. Only after a few high-level visits, during which China promised to invest $\$ 400$ billion in Turkey and to encourage Chinese tourists to visit the country, Ankara was persuaded to let the unfinished ship go, under Turkish supervision, through the strait (Storey, You, 2004, p. 83; Chan, 2015c). Finally, on $3^{\text {rd }}$ March 2002, the history of Varyag ended for good when it reached the Chinese shipyard in Dalian (Storey, You, 2004, p. 83; Chan, 2015d): after a few-years' renovation, the ship was renamed and introduced into the Chinese navy in 2012 as Liaoning (Szulc, 2013, p. 68-69; Behrendt, 2015, p. 36). In the meantime, in 2000 a different Chinese company bought in Russia the second (though chronologically the first one in service) Kiev-class aircraft cruiser. Tianman Shipbreaking Company paid nearly $\$ 8.5 \mathrm{mln}$ for Kiev, officially to scrap it; however, the agreement with Russians was amended at the end of the year and the ship, similarly to its younger sister Minsk, was transformed into a theme park/ /museum (Storey, You, 2004, p. 82).

From the current perspective it seems obvious that at the time China wanted, by purchasing several aircraft carriers over a short period, to obtain the necessary knowledge to construct such ships on its own. However, it should be borne in mind that nearly 20 years ago the perception of the PRC in the world was completely different than it is now, and the ships themselves did not seem to have any military value (Szulc, 2013, p. 67). Perhaps the secret service or policymakers suspected what the real Chinese plans regarding Varyag ${ }^{12}$ were, but at the time many people did not expect that an unequipped and unfinished hulk would be

\footnotetext{
${ }_{11}$ As it later turned out, there were three new and well-maintained engines on-board, but both parties of the transaction purposefully misinformed the world stating that Xu Zengping purchased only an unequipped hull (Chan, 2015a).

12 When the information about the purchase of the carrier was revealed, the Russian media reported that $\mathrm{Xu}$ was acting on behalf of the Chinese government. The Chinese embassy in Moscow denied this information (Storey, You, 2004, p. 83).
} 
transformed into a full-fledged ${ }^{13}$ aircraft carrier within a decade. Moreover, after another five years, the second Chinese aircraft carrier project was launched (project 001A - a modification of Liaoning; Altair, 2017; Majumdar, 2017). Such a quick progress of the Chinese aircraft carrier construction program would not have been be possible if Ukraine had not had its share in this enterprise. At this point, it should be emphasised that the role of Ukraine was not limited to the sale of the hulk which lied unused in a shipyard by the Black Sea. According to $\mathrm{Xu}$ Zenping's testimony, under the sales agreement he received also 40 tonnes of documentation (Chan, 2015b; 2015d) ${ }^{14}$, which probably accelerated significantly the process of construction of the two Chinese aircraft carriers ${ }^{15}$. It was also not without significance that the head engineer who worked on both the Kuznetsovclass ships in Ukraine was employed as a consultant (Beckhusen, 2017), likely together with some other Ukrainian engineers. It is a truism that an aircraft carrier is not just the ship itself, but also its fighting group ${ }^{16}$, and most importantly - its air group. Initially, China attempted to purchase a batch of $50 \mathrm{Su}-33$ carrier-based planes from Russia (a modernised, naval version of Su-27; see: Gunston, 1997, p. 268), but during the negotiations China limited itself to first no more than ten, and finally only made an offer for a few planes and a licence for their production in China. Moscow, obviously, did not want to accept this (probably) unprofitable transaction, undoubtedly remembering the experience of selling the licence to produce $\mathrm{Su}-27^{17}$ to China. Again it was Ukraine that helped China and consequently contributed significantly to the Chinese program of construction of carrier-based planes. After the dissolution of the Soviet Union, two prototypes of the naval version of Su-27 were preserved on the territory of Ukraine (specifically, in the Crimean Peninsula). Having been copied and re-named J-15, these planes

${ }^{13}$ Due to constraints resulting from its construction - such as lack of catapults for planes and smaller space under the deck - its abilitity to carry out air operations is curbed as well. It also cannot hold its ground against American nuclear-powered supercarriers.

${ }_{14}$ Pawel Behrendt claims that Russians sold the documentation to the Chinese in 2006 (Behrendt, 2015, p. 38). Perhaps the Ukrainian documentation was incomplete or Beijing wanted to seize any opportunity at that point.

${ }^{15}$ In an interview for South China Morning Post, the businessman quoted an anonymous Chinese naval expert who allegedly told him he saved China 15 years of independent research (Chan, 2015c; 2015d).

${ }^{16}$ China achieved major successes in building destroyer-class or frigate-class ships for over a decade (see: Nitka, 2015, pp. 86-92; Navy Recognition, 2017; Dura, 2014; Kenhmann, 2018).

${ }^{17}$ Having manufactured nearly half of the intended two hundred Su-27s (as Shenyang J-11), which the licence included, China broke off the agreement under the pretext that the planes did not fulfil the current Chinese requirements - at the same time, it did not prevent the PRC from continuing to produce an unlicensed copy (Page, 2010; Roblin, 2016). 
formed part of the air group of the first Chinese aircraft carrier, and soon probably other ships of this type (Szulc, 2013, pp. 69-74; Behrendt, 2015, p. 39).

\section{Summary}

Undoubtedly, the epic journey of Varyag and, more broadly, the Chinese programme of construction of carrier vessel and later of carrier-borne aircraft based on one of the prototypes of the naval version of Su-27 surviving in Ukraine are worthy of admiration. Apart from the sale of Bisons, it is the most visible manifestation of the process that Justyna Szczudlik-Tatar wrote about, i.e. the Chinese quest for access to post-Soviet military equipment and technology without involvement of Russia. It should be noted that Moscow, once the initial enthusiasm had waned (in the late 1990s and early 2000s), became more sceptical towards the idea of peregrination of modern technology, equipment and arms to China. It was mainly due to declining profitability of such transactions caused by unlicensed copying, and a growing competition from the Chinese arms industry which was developing rapidly and at low cost with the use of technologies obtained from Russia.

In the light of the abovementioned facts, it is clear that Ukraine as a source of military technologies, equipment and arms played a large role in development of the Chinese military potential. During the times of the Soviet Union, military production in the terrains currently belonging to Ukraine was advanced, with the presence of a large number of modern aviation and naval plants and shipyards. In effect, the Ukrainian military and industrial complex still remains relatively modern and is able to produce equipment and arms of about average - taken globally - quality (see: GlobalSecurity.org, 2017b; Górka-Winter, 2015, pp. 1-2). On the other hand, the purchase of military equipment and arms in Ukraine is for China a chance to overcome its difficulties and lower its own research and development costs. It is no accident that one of the main military "goods" transferred from Ukraine to the country beyond the Great Wall are aircraft and naval engines and radars (SIPRI, 2018a; Johnson, 2016; Kirchberger, 2015, p. 264) - it is widely known that Chinese constructors still struggle with manufacturing their own equipment of these types (Adamczyk, 2016, pp. 184-186). Together with the technological development of its own defensive system, one would expect China to become less and less interested in access to post-Soviet military technologies - still under development, but certainly not cutting-edge - via Ukraine. Interestingly, it is not really the case - although modern Russian military equipment and arms, such as Su-35 planes and S-400 rocket systems (Wezeman, 2017; Meick, 2017, 
p. 3 and following; Connolly, Sendstad, 2017, p. 8 and next) are of clear interest to China, also the older technology available in Russia and Ukraine still has the potential to attract the Chinese customer. The most recent example is the People's Republic purchase of the second (unfinished) copy of the biggest cargo aircraft in the world, An-255 Mriya (NATO reporting name: Cossack) and the license for launch of its subsequent production in China (Dsouza, 2016). In Ukraine, however, a veritable scandal broke out when Wang Jing (known for, among others, planning the construction of the Nicaragua Canal and a port in Crimea) bought the Motor Sich factory. The transaction, the entire point of which was clearly an extensive transfer of military technologies to China, was discussed in terms of putting the security of Ukraine in danger - and it ended up being annulled by the Ukrainian courts (Clover et al., 2017; Liu, 2017).

\section{References:}

Adamczyk, M. (2015). Porównanie zmiany potencjału militarnego Chin na tle Rosji, Indii, Stanów Zjednoczonych oraz Japonii w okresie od 1989 do 2013 roku. In: D. Magierek, M. Pogonowski (eds.). Aspekty bezpieczeństwa w życiu publicznym (p. 123-140). Koszalin: Wydawnictwo Uczelniane Politechniki Koszalińskiej.

Adamczyk, M. (2016). Współpraca wojskowa kluczowym elementem relacji między Federacją Rosyjską a Chińską Republiką Ludową. In: G. Libor (ed.). Oblicza wspótczesnego terroryzmu (pp. 173-192). E-book: Wydawnictwo internetowe e-bookowo.

Altair. (2014.03.04). Drugi ukraiński poduszkowiec dla ChRL. Retrieved from: http://www. altair.com.pl/news/view?news_id=12858.

Altair. (2017.04.26). Chiny zwodowaty drugi lotniskowiec. Retrieved from: http://www. altair.com.pl/news/view?news_id=22150.

Beckhusen, R. (2017.09.06). This Military Expert May Help China Even the Odds against the U.S. Navy. Retrieved from: http://nationalinterest.org/blog/the-buzz/military-expert-may-help-china-even-the-odds-against-the-us-22184.

Behrendt, P. (2015). Chińczycy graja w go. Napięcie w Azji rośnie. Warszawa: 3S Media.

Brands, H., Cooper, Z. (2018). Getting Serious about Strategy in the South China Sea. Naval War College Review, 71(1), 13-32.

Chan, M. (2015a.01.18). Mission Impossible: How One Man Bought China its First Aircraft Carrier. Retrieved from: http://www.scmp.com/news/china/article/1681710/sea-trials-how-one-man-bought-china-its-aircraft-carrier.

Chan, M. (2015b.01.19). The Inside Story of the Liaoning: How Xu Zengping Sealed Deal for China's First Aircraft Carrier. Retrieved from: http://www.scmp.com/news/china/ article/1681755/how-xu-zengping-became-middleman-chinas-deal-buy-liaoning.

Chan, M. (2015c.01.20). Mission Impossible II: The Battle to Get China's Aircraft Carrier Home. Retrieved from: http://www.scmp.com/news/china/article/1682731/mission-impossible-ii-battle-get-chinas-aircraft-carrier-home. 
Chan, M. (2015d.01.29). "Unlucky guy” Tasked with Buying China's Aircraft Carrier: Xu Zengping. Retrieved from: http://www.scmp.com/news/china/diplomacy-defence/article/1779703/unlucky-guy-tasked-buying-chinas-aircraft-carrier-xu.

Clover, C., et al. (2017.10.05). Chinese Deal with Ukraine Defence Group Raises Hackles. Retrieved from: https://www.ft.com/content/e8aed9f4-a1dc-11e7-9e4f-7f5e6a7c98a2.

Clover, C., Jiu, S.F. (2016.11.03). Russia Resumes Advanced Weapons Sales to China. Retrieved from: https://www.ft.com/content/90b1ada2-a18e-11e6-86d5-4e36b35c3550.

Connolly, R., Sendstad, C. (2017). Russia's Role as an Arms Exporter. The Strategic and Economic Importance of Arms Exports for Russia. Londyn: Chatham House.

Defence24.pl. (2015.05.15). Ukraiński przemyst zbrojeniowy: as w rękawie Kijowa? Retrieved from: http://www.defence24.pl/224293, ukrainski-przemysl-zbrojeniowy-as-w-rekawie -kijowa.

Donaldson, R.H., Donaldson, J.A. (2003). The Arms Trade in Russian-Chinese Relations: Identity, Domestic Politics, and Geopolitical Positioning. International Studies Quarterly, 47(4), 709-732.

Dsouza, L. (2016.10.03). China Plans to Resurrect The World's Largest Plane by Restarting Antonov AN-225 "Mriya" production. Retrieved from: https://www.defenceaviation. com/2016/10/china-plans-to-resurrect-the-worlds-largest-plane-by-restarting-antonov-an-225-mriya-production.html.

Dura, M. (2013.05.28). Chiny otrzymaty pierwszy duży poduszkowiec desantowy typu Bison. Retrieved from: http://www.defence24.pl/1841,chiny-otrzymaly-pierwszy-duzy-poduszkowiec-desantowy-typu-bison.

Dura, M. (2014a.08.16). Chińska ekspansja na oceany. Nowe krążowniki „AEGIS”. Retrieved from: http://www.defence24.pl/115163, chinska-ekspansja-na-oceany-nowe-krazowniki-aegis.

Dura, M. (2014b.12.05). Grecy sprzedaja rosyjskie poduszkowce do Chin. Retrieved from: http://www.defence24.pl/164523,grecy-sprzedaja-rosyjskie-poduszkowce-do-chin.

Gawęda, M. (2015.09.12). T-84 Opłot-M. Najnowszy czołg ukraińskiej armii. Retrieved from: http://www.defence24.pl/258246,t-84-oplot-m-najnowszy-czolg-ukrainskiej-armii.

GlobalSecurity.org. (2017.12.30). Ukraine Defense Industry. Retrieved from: https:/www. globalsecurity.org/military/world/ukraine/industry.htm.

GlobalSecurity.org. (3.01.2018). FN-6 MANPADS. Retrieved from: https://www.globalsecurity.org/military/world/china/fn-6.htm.

Górka-Winter, B. (2015). Potrzeby modernizacyjne ukraińskiej armii - perspektywy dla przemysłu zbrojeniowego. Biuletyn PISM, 1285(48), 1-2.

Gunston, B. (1997). Wspótczesne samoloty wojskowe. Warszawa: Muza SA.

Hellenic Navy. (2018a). Amphibious Operations Command. Retrieved from: http://www. hellenicnavy.gr/en/organization/fleet-headquarters/fleet-headquarters-commands/ amphibious-operations-command.html.

Hellenic Navy. (2018b). Fleet. Retrieved from: http://www.hellenicnavy.gr/en/fleet.html. Holmes, J.R. (2014). Strategic Features of the South China Sea. A Tough Neighborhood for Hegemons. Naval War College Review, 67(2), 27-44.

Iwański, T. (2012). Ukraina, Białoruś i Mołdawia wobec ekspansji gospodarczej Chin w Europie Wschodniej. Komentarze OSW, 79, 1-7. 
Johnson, R.F. (2016.02.17). PRC Military Continues to Depend on Ukrainian Defense Technology. Retrieved from: https:/www.ainonline.com/aviation-news/defense/2016-02-17/ prc-military-continues-depend-ukrainian-defense-technology.

Kaczmarek, P. (2012). Archipelag Senkaku. Źródło napięć na Morzu Wschodniochińskim. Refleksje, 5, 61-73.

Kalman, B., Watson, E., Deiss, D. (2016.11.09). China's Naval Power: Growing Amphibious Capabilities in the South and East China Seas. Retrieved from: https://www.globalresearch. $\mathrm{ca} /$ chinas-naval-power-growing-amphibious-capabilities-in-the-south-and-east-china-seas/5555936.

Kamiński, T. (2015). Sypiając ze smokiem. Polityka Unii Europejskiej wobec Chin. Łódź: Wydawnictwo Uniwersytetu Łódzkiego.

Karczewski, M. (2011). System kontroli i regulacji międzynarodowego handlu uzbrojeniem. Przeglad Strategiczny, 2, 59-72.

Kenhmann, H. (2018.01.07). Type 055: Les «secrets» de fabrication pour le plus grand destroyer chinois. Retrieved from: http:/www.eastpendulum.com/type-055-les-secretsde-fabrication-pour-le-plus-grand-destroyer-chinois.

Kirchberger, S. (2015). Assessing China's Naval Power. Technological Innovation, Economic Constraints, and Strategic Implications. Berlin: Springer Berlin Heidelberg.

Kreutz, J. (2004). Reviewing the EU Arms Embargo on China: the Clash between Value and Rationale in the European Security Strategy. Perspectives: The Central European Review of International Affairs, 22, 43-58.

Kuźniar, R. (2006). Międzynarodowe stosunki polityczne. In: E. Haliżak, R. Kuźniar (ed.). Stosunki międzynarodowe. Geneza, struktura, dynamika (p. 119-141). Warszawa: Wydawnictwa Uniwersytetu Warszawskiego.

Macenowicz, M. (2015). Transparentność zobowiązań państw w zakresie handlu bronią. Zagadnienia prawne. Krytyka Prawa. Niezależne studia nad prawem, 7(1), 263-280.

Majumdar, D. (2017, February 22). China's Second Aircraft Carrier Is Almost Complete (And 4 More Could Be Coming). Retrieved from: http://nationalinterest.org/blog/thebuzz/chinas-second-aircraft-carrier-almost-complete-4-more-could-19542.

Malyasov, D. (2017.08.25). Fifth Zubr-Class Large Air-Cushion Landing Craft Spotted in China. Retrieved from: http://defence-blog.com/news/fifth-zubr-class-large-air-cushion-landing-craft-spotted-in-china.html.

Meick, E. (2017). China-Russia Military-to-Military Relations: Moving Toward a Higher Level of Cooperation. Waszyngton: U.S.-China Economic and Security Review Commission.

Miller, D., Miller, C. (1994). Wspótczesna wojna morska. Warszawa: Espadon.

Molo, B. (2008). Podstawowe pojęcia i kategorie międzynarodowych stosunków politycznych. In: E. Cziomer (ed.). Międzynarodowe stosunki polityczne (p. 18-37). Kraków: Krakowskie Towarzystwo Edukacyjne.

Muczyński, R. (2016.11.20). Chiny: Największy poduszkowiec świata zbudowany w kraju przekazany marynarce wojennej. Retrieved from: http://www.nowastrategia.org.pl/ chiny-najwiekszy-poduszkowiec-swiata-zbudowany-w-kraju-przekazany-marynarcewojennej/. 
Navy Recognition. (2017.06.29). Chinese Cruiser or Destroyer? Full Details on PLAN's First Type 055. Retrieved from: http://www.navyrecognition.com/index.php/focus-analysis/naval-technology/5337-chinese-cruiser-or-destroyer-full-details-on-plan-s-firsttype-055.html.

Nitka, A. (2015). Europejskie tournée chińskich okrętów. Nowa Technika Wojskowa, 286(3), 86-92.

Page, J. (2010.12.04). China Clones, Sells Russian Fighter Jets. Retrieved from: https://www. wsj.com/articles/SB10001424052748704679204575646472655698844.

Rangsimaporn, P. (2006). Russia's Debate on Military-Technological Cooperation with China: From Yeltsin to Putin. Asian Survey, 46(3), 477-495.

Roblin, S. (2016.07.24). China Stole This Fighter From Russia and It's Coming to the South China Sea. Retrieved from: http://nationalinterest.org/feature/china-stole-fighter-russia\%E2\%80\%94-its-coming-the-south-china-sea-17087.

RT. (15.08.2011). China Hunts for Both Soviet and US Military Technology. Retrieved from: https://www.rt.com/politics/soviet-china-military-technology/.

Sabak, J. (2016.09.01). Największy transportowiec świata powstanie w Chinach. Licencja na An-225. Retrieved from: http://www.defence24.pl/439360,najwiekszy-transportowiec-swiata-powstanie-w-chinach-licencja-na-an-225.

Smith, P.J. (2013). The Senkaku/Diaoyu Island Controversy. A Crisis Postponed. Naval War College Review, 66 (2), 27-44.

SIPRI. (2017a.12.30). TIV of Arms Exports from Ukraine, 2010-2016. Retrieved from: http://armstrade.sipri.org/armstrade/html/export_toplist.php.

SIPRI. (2017b.12.30). TIV of Arms Exports from the Top 50 Largest Exporters, 2010-2016. Retrieved from: http://armstrade.sipri.org/armstrade/html/export_toplist.php.

SIPRI. (2018a.01.02). Trade Registers. Retrieved from: http://armstrade.sipri.org/armstrade/page/trade_register.php.

SIPRI. (2018b.01.08). Arms Embargoes. Retrieved from: https://www.sipri.org/databases/ embargoes.

SIPRI. (2018c.01.08). TIV of Arms Exports to China, 1992-2016. Retrieved from: http:// armstrade.sipri.org/armstrade/html/export_values.php.

Stosunki międzynarodowe. (2018.01.08). Handel bronia. Retrieved from: http://stosunki-miedzynarodowe.pl/slownik/54-h/528-handel-bronia.

Storey, I., You, J. (2004). China's Aircraft Carrier Ambitions: Seeking Truth from Rumors. Naval War College Review, 57(1), 27-44.

Szczudlik-Tatar, J. (2011). Polityka Chin wobec pozaunijnych państw „nowej Europy Wschodniej”. Biuletyn PISM, 852(104), 2553-2554.

Szulc, T. (2010). Chiński śmigłowiec Z-9. Nowa Technika Wojskowa, 225(2), 70-79.

Szulc, T. (2013). Potęga morska Związku Radzieckiego odradza się w... Chinach! Nowa Technika Wojskowa, 261(2), 69-72.

UNROCA. (2018.01.02). Retrieved from: https://www.unroca.org/.

US Naval Institute Staff. (27.10.2015). China's Military Built with Cloned Weapons. Retrieved from: https://news.usni.org/2015/10/27/chinas-military-built-with-clonedweapons. 
Wang, B. (2013.03.30). Ukrainian Aircraft Design Expertise to the Highest Bidder. Retrieved from: https://www.nextbigfuture.com/2013/03/ukainian-aircraft-design-expertise-to.html.

Wezeman, P.D., Wezeman, S.T. (2015.09.18). The 2015 UN Register on Conventional Arms: Still Time to Improve. Retrieved from: https:/www.sipri.org/commentary/expert-comment/2015/2015-un-register-conventional-arms-still-time-improve.

Wezeman, S.T. (2017.07.05). China, Russia and the Shifting Landscape of Arms Sales. Retrieved from: https://www.sipri.org/commentary/topical-backgrounder/2017/chinarussia-and-shifting-landscape-arms-sales.

Wolski, J. (2016a). Czołgi rodziny T-72 w konfliktach zbrojnych. Nowa Technika Wojskowa, 301(6), 38-51.

Wolski, J. (2016b). Syryjski poligon: ppk kontra czołgi. Nowa Technika Wojskowa, 307 (12), 46-53.

Zaloga, S.J. (2011). T-80 Standard Tank: The Soviet Army's Last Armored Champion. E-book: Osprey Publishing.

Zhao, L. (2017.09.20). Project with Ukraine to Bolster Nation's Aircraft Engine Capability. Retrieved from: http://www.chinadaily.com.cn/world/cn_eu/2017-09/20/content_322 29794.htm.

Zhen, L. (2017.09.16). Chinese Firm's Stake in Ukraine Military Aircraft Engine Maker "Frozen". Retrieved from: http://www.scmp.com/news/china/diplomacy-defence/article/2111493/chinese-firms-stake-ukraine-military-aircraft-engine. 